\title{
The internationalization process of graduate studies in Brazil
}

\author{
Angela Sugamosto Westphal \\ Universidade Católica de Brasilia \& CAPES \\ nutrica@yahoo.com.br
}

\begin{abstract}
The article presents, through bibliographical research and historical analysis, the role of Brazilian Federal Agency for Support and Evaluation of Graduate Education - CAPES in the process of internationalization of graduate education in Brazil, as a fomenter of access for training of Doctors, researchers and students abroad. For this, it is necessary to understand politics with basis on bilateral agreements with the World Bank, WTO, OECD and others. This discussion is based on a collection of important historical events that led Capes to propose goals, democratizing the access to graduate education. The study is relevant as it reflects the current government's attention with the conduction of public policies in relation to technological scientific interests and, consequently, economics of the country. Despite the social and political history of the country and, consequently, from difficulties for an active internationalization of higher education, it is concluded that recent initiatives of the Brazilian state have increased the possibility of strengthening the capacity of scientific production and circulation of knowledge between academic pairs, because the research and graduate education re evaluated by the degree of internationalization of their programs and outcomes.
\end{abstract}

\section{Introduction}

Education is strategic for the development of countries and, exactly for this reason, in the last decade has received, increasingly, a strong world pressure. In this context, educational policies were influenced by globalization and by their own need to globalize, emerge initiatives from government not only to try improve the educational level of their respective countries, but also equalize or, at least, reduce the differences that exist between the education systems. The contemporary trend is to intensify the international flow of goods, services, capital and information that widely influence people's knowledge and, consequently the offers of specialized educational demands. The internationalization of education corresponds to a deliberate process of introduction of international dimensions from intercultural character, in all aspects that involve the activities of education and research. International experience presents itself as an important component for analysis of the national education systems. The universal nature of knowledge associated with the tradition of academic cooperation, in development of education activities, since antiquity, are factors that contributed to influence the international character of universities since their origin (Knight, 2005 \& Minogue, 1981).

The internationalization of studies in the higher level configures itself as a strategy of construction of borders that produces credentials in the competitive world of labor and in the symbolic market of diplomas. Globalization processes of economy and culture, apparently homogeneous, from the standpoint of capitalist production, produce consequences that expand social segregation at the local, national and international sphere. The adoption of public policies from governmental character merely, neoliberal, focuser, or universals are only in the speech and on papers as fundamental to neoliberal principles, end up contributing a lot to the maintenance of poverty and social inequality than to its reduction (Knight \& Guimarães, 2005, 2009, p.124).

Even having adopted national contours, to be subordinated to the interests of each Nation-State (19th century), the university did not annul its universal dimension as national governments have institutionalized international cooperation policies with the implementation of

Cultural and Pedagogical Inquiry, 2013, 5(1), pp. 4-13

ISSN 1916-3460 (C) 2013 University of Alberta

http://ejournals.library.ualberta.ca/index.php/cpi/index 
exchange programs for students, teachers and researchers willing to foment and to disseminate knowledge (Rossato, 1998). The regulatory and acting policies of the internationalization of higher education in Brazil have been redirected in accordance with the interests of the Global North, mainly by the diffusion of the ideals of the Bologna process in 1999. The Bologna Process was based on a supranational educational policy, directed to state-members of the European Union with the aim of building an "European space of higher education", making accessible and harmonized to academic backgrounds taught in higher education at several countries which underwrote it (Lima, Azevedo \& Catani, 2008).

A great example of this is the agreement of education being made between Brazil and other countries. The most known one is the science without borders program - SWB, created in 2011 by the federal government. Science without Borders is a program that seeks to promote the consolidation, expansion and internationalization of science and technology, innovation and thus, Brazilian competitiveness through exchange and international mobility. This Program is the main Brazilian internationalization policy of higher education, because it fulfills an essential role to open Brazil to the world, allowing Brazilians to have access to different areas of knowledge in different countries.

The activities promoted in the scope of higher education are presented as something thaton that interested strongly the Brazilian government, the Brazilian and foreign universities, as well as fomentation agencies like CAPES (Brazilian Federal Agency for Support and Evaluation of Graduate Education) and $\mathrm{CNPq}$ (National Counsel of Technological and Scientific Development). This phenomenon indeed, is the essence of the academic internationalization's" process.

The graduates in Brazil occupy central space in the scientific production of the country, due to the fact that most of researchers and funding resources for researches is linked to graduate programs. The CAPES, agency attached to MEC (Ministry of Education) is responsible for graduate studies in Brazil.

The fomentation of these programs will shorten the previously delinked situation of Brazil where the country relied on its exclusionary educational policies and programs. The country needs to invest in knowledge development, produce science, innovate and absorb technology. Due to the importance of that phenomenon for universities and Brazilian fomentation agencies, it is important to discuss the realities/structures of internationalization with special focus on the role of CAPES in that process.

\section{Internationalization of graduate education}

From the 90's on, the process of globalization has intensified the phenomenon of internationalization in the educational and academic areas. What once was an alternative to universities became a requirement to the extent that labor markets transposed the territorial barriers of scientific knowledge and education.

According to Morosini (2009) the "Internationalization of Higher Education" is considered as any systematic effort that has as objective to make higher education more correspondent to the requirements and challenges related to the globalization of society, economy and labor markets.

Iinternationalization means, literally, the process of becoming international. This meaning can be added to a hypothesis of institutional nature and another one of academic nature. At the institutional line, internationalization can be understood as a process focused to the mere acquisition of internationally renowned knowledge for the benefit of a certain Higher Education Institution (HEI), through the offering of courses that are internationally popular, events of international mien and/or, via the large number of publications of researchers in international periodicals (Marrara, 2007). According to the author, that vision of internationalization is nothing more than a marketing tool used by HEI, aiming to find new customers for its services.

Under the academic focus, the internationalization of education provides the realization of complementary experiences to the educational process in the scope of undergraduate and graduate learning. That process contributes to the development of education and science, through the 
collaboration and exchange of experience with foreign agents (Marrara, 2007). This type of internationalization predicts large investments in benefits granted to fellows to realize their research, to study or participate in events abroad. That participation is only possible with the acting of federal agencies such as CAPES, CNPq and some other state agencies. The fomentation agencies are fundamental to the creation of research centers through collective exchanges.

The Internationalization of Higher Education has its own models, such as peripherals and central ones. The first covers the institutions and the other the "internationalization of higher education" which deals with institutional models at an international scope (Morosini, 2006). The peripherals models speaks about the internationalization which focuses on research activities, as it is the case of graduate programs, teachers exchange programs, researches and students.

The model of internationalization predominant, in the Brazilian context, is peripheral. It is important to observe that the peripheral model does not deal just with institutional levels, it also has connections with the Brazilian national system of higher education.

Traditionally, the reasons for internationalization have been presented in four groups: sociocultural, political, academic and economic. As well as the human resource development, strategic alliances, trade, capacity of building and especially, cultural, social development and mutual understanding (Leuze, Martens and Rusconi, 2007).

For Krawczyk (2008), the creation of International Cooperation Programs has followed four trends: 1) Training undergraduate and graduate programs, 2) Joint research programs between countries, 3) Training programs in local human resources and, 4) Inter-institutional training programs. According to the researcher, the international cooperation of internationalization policies of universities is divided between the development of human resource and scientific and technological development. It is important to highlight that forms of international cooperation are not just that, but that its_focus has a tendency for those two areas.

Morosini (2006) noted that relevant points in policy and program agreements are approaches made through bilateral or multilateral relations.

Another relevant point in policies is its direction, whether it is for undergraduate or graduate students, for teachers/researchers or both. As well, with which countries those international cooperation are related to, it could be with Ibero-American countries or no.

Moreover, one should also consider the type of regionalization, if it is Inter-regional (the relations between nations of the same region and/or between higher education institutions of nations within the same region), Regional (inter-relations between nations of a continent), Trans-regional, (the relations between different regions) or Supra-regional (relations arising from the work of international organizations of higher education, such as UNESCO). Morosini (2006) still complements that the nature of these policies can be made through agreements or programs.

Thus, it can be observed that the harmonization is turned to the regulation and appropriateness of methods, relating as well within the formation of scope and research. The Joint Research has greater focus, obviously, in research, and the exchange, greater focus in training and improvement.

\section{Internationalization policies in Brazil: Role of CAPES}

The policy and the nature of graduate studies in Brazil are almost exclusively defined by the state (responsible for financing, regulating and defining its politics) as well as the participation of public universities and research institutes that fall under its mandate. In this context, the effectiveness of the first international cooperation programs was attached to the creation of universities and the government's own political desire.

It is believed that the beginning of international cooperation policy in the country occurred in the 30's, when the Federal Government created four consecutive universities: Federal University of Rio de Janeiro (1920), Federal University of Minas Gerais (1928), Federal University of Rio Grande do Sul (1934) and University of São Paulo (1934) (Rossato, 1998). 
The internationalization of Brazilian higher education between 1930 and 1950 was induced by public policies formulated by the Federal Government, and by actions executed by government agencies focused on the strengthening of public universities and teacher training, indispensable to the consolidation of the academic project of those emergent institutions resulting from the union of conglomerates of isolated institutions (Rossato, 1998). In that period, these were influence by French academic culture (university of power) and American academic norms (university of progress) in formation of the academic system of the country.

Those facts motivated Cunha (2007) to affirm that the process of modernization of Brazilian higher education in Brazil, based on the North American model, settled in the 40's, was strengthened in the 50's, but only intensified in the 60's with the military governments.

In July 1951, through the Decree n. 29.741, CAPES was created - The Brazilian Federal Agency - for support and evaluation of graduate education, linked with the Ministry of Education, with a commission to promote capacitation and improvement of human resources in higher levels of education. The concession of scholarships started in 1953 with the implantation of the Academic Program as the main work of CAPES at universities and institutes of higher education. Anísio Teixeira was designated general secretary of the committee intended to promote the Improvement of Higher Education Personnel. He served as institutional policy formulator of CAPES, who hired foreign visitor teachers, stimulated the activities of exchange and cooperation between institutions, granted scholarships and gave support to events of scientific nature. In that period, 79 scholarships were awarded: two for training in the country, 23 for improvement in the country and 54 overseas (Brazilian Federal Agency for support and evaluation of graduate education [capes] 2011a).

In the period between 1960 and 1970, internationalization continued and was influenced by public policies formulation that focused on the consolidation of the national system of higher education. They didn't crave only to motivate the modernization of higher education, but also to educate researchers and professionals with the required expertise by the modernization project of public institutions and the diversification of the industrial national program (Cunha, 2007).

From that on, consultancies that aimed at legitimating the elaboration of a Brazilian university reform were created. To fulfill such demand, agreements of cooperation with American universities were reinforced, with the presence of teachers, consultants, investments in graduate programs, and a big number of scholarships (with rising in the masters and doctors levels).

In 1964, the intention was to distribute 120 scholarships per year, but only managed 20 . In 1974 CAPES held one thousand fellowships in the country and 70 abroad, and by 1978, the concessions totalized 13 thousand in Brazil and 1200 abroad.

In that period, manifestations of resistance from the students and the teachers contrary to the type of intervention exercised for consultants occurred. After the publication of the Institutional Act n. $5^{1}(12 / 1968)$, the manifestations against the interventions of American consultants in the educational sector were controlled and, for a period of five years, they managed to guide the university chiefs in the direction of the administrative and pedagogical restructuring of the university, as prescribed in the North American model (Cunha, 2007). With the world oil crisis and its repercussions on the financial health of the country in 1973, the cooperation agreements, were interrupted.

During the period from 1975 to 1989, three National Plan of Graduate (NPG) we promoted, with guidelines intended for the successful trajectory of stricto sensu graduate in the country and the political base of CAPES for graduate education. Only in 2004, the elaboration of that referring to the period of 2005-2010 was retaken. Continuing the five previous plans, the NPG 2011-2020 was elaborated. The plan was developed with suggestions and eminent persons' studies from several experts from different areas of knowledge and education, as well as from the scientific community and universities. The national plan of graduate education (NPG) 2011-2020 aims at

\footnotetext{
${ }^{1}$ The Institutional Act No. 5 or IA-5 was the fifth in a series of decrees issued by the Brazilian military regime in the years following the 1964 Military coup in Brazil. The IA-5 overlapping the Constitution of January 24, 1967, as well as the state constitutions, gave extraordinary powers to the Republic President and suspended several constitutional guarantees.
} 
setting new guidelines, strategies and goals to give continuity and advance proposals for the policy of graduate education and research in Brazil. Alongside this plan, the new National Education Plan (NEP) is being drawn up. In fact, for the first time, a national education plan will contemplate the goals of graduate education, this because the NPG will be an integrant part of NEP (CAPES, 2010b).

Between 1980 and 1990, the federal government invested in the scientific development of the public universities. This action was responsible for the expansion of stricto sensu graduate programs offered in the country. The programs were considered strategic and exercised triple role: collaboration to consolidate the higher education system, for they had as one of their responsibilities to train form teachers and researchers that met the needs of the public and private systems of the higher education sector. Also, they had to lead production processes spreading knowledge capable to boost the economic development of the country; and to capacitate professionals to attend to the challenges of a country in development (Velho, 1998).

On that occasion, the articulated actions between representatives of the Ministry of Education, Ministry of External Relations and Ministry of Science and Technology were responsible for the expansion of the internationalization process of higher education associated with the action plans realized by government agencies.

With the objective to multiply providers of international cooperation programs, the CRBU was created (Counsel of Rectors of Brazilian Universities), and the Advice Forum of Brazilian Universities for International Affairs (committed mainly to the elevation of the training of teachers and researchers, the development of expertise in strategic areas and strengthening of courses and institutions) was realized. In the 80 's, the distribution of scholarships began to have as its premise the evaluation of grades for courses. That would be one of the most powerful explanations for the success of graduate education in Brazil, in others words, the automatic bond between grade, and number of scholarships and aid for programs (CAPES, 2011c).

The 90s decade changed the graduate stricto sensu evaluation criteria. With that, the universities were pressed to exploit the international cooperative potential of agreements, as an important part of their pedagogical and institutional development projects, having grades six and seven restrained to programs well-recognized at the international level (Monteiro, 2007).

From 2000 on, in the world sphere, a public disinvestment in higher education and the consequent privatization process occurred in several national systems of higher education which made the internationalization of education lose a great part of the state endorsement which led to some commercializatkion aspects. In that period, CAPES the CAPES Portal of Periodicals, an initiative that allowed a qualitative and quantitative leap in academic work. The CAPES Portal of Periodicals is one of the largest virtual libraries of world, gathering high level scientific content available to the Brazilian academic-scientific community (CAPES, 2011d).

With the transformation of the university into a service with access, not through citizenship, but via the means of consumption, basically through payment, the right to education suffered radical erosion. The elimination of gratuity of university education and the replacement of scholarships for loans were the instruments of transformation of students into consumers. All that because of an educational ideology centered on individualism and individual autonomy (Santos, 2010).

In 2001, CAPES' bi-national university partnerships began, with the objective of mainly, increasing undergraduate students exchange programs, as well as to foment the exchange of graduate students and teachers. Those partnerships were implemented between Brazilian and foreign universities with the assurance of the mutual recognition of credits for students. Giving contribution to these partnerships, it was released in July 2011, a Federal Government program called "Science without Borders" which was an agreement firmed between Brazil and sundry countries that seek to promote the consolidation, expansion and internationalization of science and technology, of innovation and Brazilian competitiveness through exchange of students in undergraduate and graduate education and in international mobility. The project provides the concession of 101,000 scholarships that will be granted by the Federal Government, of these 26,000 will be awarded with funds from the private sector (CAPES, 2011e). 
With the consolidation of the stricto sensu graduate and the need for enrollment expansion in undergraduate programs, it was noticed that the international scholarship program which had a greater growth was the Sandwich Doctorate: while in 1996, CAPES granted 146 scholarships (CAPES apud Franco, 2002, p.313), in 2011 there was a steady growth, and this number increased to 1890 (GeoCAPES, 2011).

The CAPES objectives the foment the development of such activities turned into the academic improvement and educational development of Institutions of Higher Education (IHE), research centers and teachers, thus, expanding and consolidating the stricto sensu graduate program (Mastesr and Doctorate) all over the country. This was one of the main activities developed is the investments of the training of high level resources in the country and abroad and promotion of the international scientific cooperation, in others words, develop the activities of Brazilian graduate education in the global context.

Six decades ago, Brazil counted with a little more 60 thousand students in higher education and the graduate level barely existed. In 2011, 60 years after the creation of CAPES, more than 50, 000 students were registered in Master's courses, and 12,000 in Doctorate courses.

Currently, the country has 3,157 programs of stricto sensu graduate programs, with 4,722 courses: 2,752 Masters, 1,618 Doctorates and 352 professionals Master's programs. By 2008, Brazil has reached the $13^{\text {th }}$ position in world classification of scientific production. On scientific production, Brazil surpassed Russia (15th) and the Netherlands (14th.). with 19,436 articles in 2007, the production increased to 30,451 publications in 2008 (CAPES, 2011f).

\section{Influence of International Organizations (IOs) in Internationalization of Higher Education}

In that last decade, strong change in policies and programs of World Bank was undertaken. Its operational focus goes to issues of educational reform giving attention to the political feasibility of structural reforms and to social costs associated with these reforms (Borges, 2003).

According to Ayres (1983), the World Bank pretends to create a reputation of technical neutrality, like it was an 'apolitical institution', but that their projects reflect deeper economic objectives. The success of the development model imposed by the World Bank depends on profound changes in political and social engineering of societies in which it operates. The financing of education policies grew a lot in the last decades, signaling a clear change of priorities. (World Bank Institute [WBI], 1999).

The world expenses on education ascended to 2000 billion dollars, more than double of the global automotive market. Eeducation has thus become an attractive area and of great potential for a capital eager for new areas of appreciation (Santos, 2010).

The construction of this and of current context should be primarily reassembled to better understand their deriving transformations, in particular, the crisis of capitalism in the 70's, as well as the Welfare State itself and the Fordist-Taylorist production model. The consequent process of capital globalization and flexibilization of its accumulation, especially in 1990 with the more clear adoption of neoliberal policies, delegated the market the role of the carrier agent for a rationality that is presumably capable of unified and self-regulateed society across the globe (Dourado, 2003).

Recently the OECD (Organization for Economic Co-operation and Development) has become a major participant in education policy; it has increasingly become involved as an influential agent, shaping speeches and references in educational policy. The OECD changed its approach, whereas in the past, it focused on the state individually, now it compares the states with each via one uniform, standardized criterion. These direct comparisons generate statistics related to the development of education and puts states under greater pressure to reform their systems, because they make this information more easily accessible and interpretable for politicians, media and the broader public (Kerstin, 2007).

Since the 90's, countries have experienced innumerous changes in the education area. Leuze et al. (2007) commented that these changes cover new forms of international regulamentation as 
standardization of new international comparative evaluations, quality assurance systems, as well as new ways to offer education using companies of private education.

As a new form of international regulation, one can also be cite the Bologna Process or the General Agreement on Trade in Services (GATS). In response to these requirements, educational policy was prioritized in national and international policy agendas and that led to intense debates about the goals and means of education.

In 2002, the US OECD Forum concluded that the global market of education was becoming a significant part in the world trade of services. From there emerged proposals that preside the education reform proposed by the World Bank and most recently the idea of reconversion of that bank into knowledge enterprise. Deriving from these proposals is that the structuring of the General Agreement on Trade in Services (GATS) in education area currently under negotiation in the World Trade Organization occurred. That transformation of higher education to educational merchandise is a long-term goal and that horizon is essential to understand the intensification of transnationalization of those markets (Santos, 2011).

These changes that are occurring in education are attributed to two main trends: the growing activity of International Organizations (IOs) and the growing marketization of the Education area (Leuze et al. 2007). The international organizations model sees the educational governance in two main aspects: first, the IO actively, promotes coordinated learning through life, especially as it in relates to national contexts and, thus, executes governance in educational policy. Second, their commitment is linked to the increasing activities of non-state agents of education, because the crescent educational demand in the context of learning through life can also solicit new nongovernmental involvement (Jakobi, 2007).

The economic and political importance acquired through knowledge exercised strong influence on the way the internationalization of higher education is thought and organized by the countries and actors implicated (Leher \& Schocuglia, apud Lima \& Contel, 2005, 2008, 2009). Education is transformed into a tradable commodity, growing the competition between States in the interest of dominating this international market. That explains the variety of terms used to translate this movement that contemporaneously is far from involving aspects strictly academic, thus showing the real market forces involved (Lima \& Contel, 2009).

The integrated education system loses the characteristic of providing_services to the market and follows a neoliberal logic. The interests of the World Trade Organization (WTO) include education only as an investment that becomes manipulated for market purposes, thus assuring its commodification (Leuze et al. 2007).

The Brazilian government has become proactive in intensifying the policy of internationalization of higher education in the country; this is not detached from the work of the WTO, but as well with its regulations, commitments and general obligations that apply directly and automatically to all members of society. The impact of these determinations on pedagogical methods and in the organizational structure of educational institutions is big, especially in relation to the commercialization of training and education (Catani, 2006).

International Organizations expanded education into other arenas of international politics thus expanding their action fields. That new international interest about the education domain in other countries causes a change in the focus of policy acting in education. Before, education was, fundamentally, state responsibility and a central element of its sovereignty and autonomy; today IOs and self-interested agents of internationals market are increasingly infiltrating educational policy objectives and outcomes (Leuze et al. 2007).

\section{Conclusion}

The possibilities of nation development depend on progressive investment in human resources training and the exapansion of science and technology.

In the scope of cultural change, since the creation of CAPES, in the 50's, up to today, it is possible to realize the changes of the institution in the organization of courses and programs 
mandated to it. The changes that occurred were produced by conceptions and assumptions based on the context of State reforms and reconfiguration of the world capital. This period was marked by the strong characteristic of an economic planning based on a capitalist model of market forces, and with respect to international organizations like the World Bank and International Monetary Fund.

It is noticed that in the context of the process of internationalization of the Brazilian higher education system, the priorities established by the State only materialized with actions that approached the government and public institutions of higher education.

Countries are being forced, due to the new demands of a competitive higher education, to establish new structures of regulation to certify the quality and recognition of national education.

We know that the goals, besides economic, were also to amplify_the conditions which favored the development of expertise capable to responding to challenges imposed by the development project of the country. The fortification of stricto sensu graduate education is occurring more strongly only recently, with investments from the public sector. It is observed that this fact occurred due to the growth of competition in the education market, as well as by pressure from International Organizations, and of course, by the needs imposed by the knowledge economy itself. As a consequence, the process of internationalization gains new motivations and multiple providers.

Considering the question that guides the research, it is possible to be sure that the process of Internationalization of Higher Education (HEI) is one of the priorities of the Brazilian HEI leaders, both public and private.

Even with a significant increase in the number of graduate programs and considerable improvement in the world classification in scientific production, challenges are still enormous and should be reflected upon seriously.

We know that resources are restrained, and whether at the national, internationals and/or multilateral levels, Brazil strives to attract resources to invest on international formation for teachers, researchers, favoring the formation and expansion of its academic credibility in Brazil and abroad. CAPES enables fomenting the improvement of higher level personnel, and its attached policies of academic exchanges.

The scholarships distribution policy abroad fomented by agency allowed that academic exchange programs were not restricted to the academic elite, as in other times and traditions. This is a considerable improvement for the internationalization of the graduate system; however, much more needs to be done, especially because the Brazilian graduate program is part of a country which still has a large educational deficit to overcome.

\section{References}

Ato Institucional $\mathrm{n}^{\circ}$ 5, de 13 de dezembro de 1968. (1968). Recovered on October 10, 2011 at http://www.camara.gov.br/internet/jornalcamara/materia.asp?codMat=42437\&pesq=aces $\underline{\text { sado }}$

Ayres, R. (1983). Banking on the poor: the World Bank and world poverty. London: The MIT Press. Borges, A. (2003). Governança e Política Educacional: Agenda recente do Banco Mundial. Revista Brasileira de Sceincias Sociais, Vol. 18, no. 52, pp. 125-138.

CAPES. (2011 a). Revista Comemorativa - Capes 60 anos. Recovered on July 11, 2011, on http://capes60anos.capes.gov.br/images/stories/download/Revista-Capes-60-anos.pdf .

CAPES. (2011b). Relatório de Gestão 2011- 2020. Recovered on october 10, 2011 at http://www.capes.gov.br/sobre-a-capes/plano-nacional-de-pos-graduacao/pnpg-2011$\underline{2020}$

CAPES. (2011c). - Cooperação Internacional. Recovered on October 10, 201 at http://www.capes.gov.br/cooperacao-internacional.

CAPES. (2011 d). Portal de Periódicos. Recovered on October 10, 2011 at http://www.periodicos.capes.gov.br/index.php. 
CAPES. (2011 e). Graduação Sanduíche no EUA - Ciência sem Fronteiras. Recovered on October 10, 2011 at http://www.capes.gov.br/ciencia-sem-fronteiras/chamada-012011-graduacaosanduiche-nos-eua.

Catani, A. C.(2006). A influência dos organismos internacionais nas políticas educacionais para a educação superior no Brasil. Curitiba. 91 f. Dissertação (Mestrado em Educação) Pontifícia Universidade Católica do Paraná, Curitiba.

Cunha, L. A.(2007). A universidade crítica: o ensino superior na república populista, $2^{\mathrm{a}}$ ed. São Paulo: Unesp.

Dourado, L. F.; Catani, A. M.; Oliveira, J. F. (orgs). (2003). Políticas e gestão da Educação Superior: transformações recentes e debates atuais. São Paulo: Xamã; Goiânia: Alternativa, p. 9.

Franco, M.E.(2002). Globalização, internacionalização e cooperação interinstitucional. In Soares, M. S, A. (coord.). A educação superior no Brasil. Porto Alegre: Unesco /IESALC/Capes.

GeoCAPES.(2011). Dados Estatísticos. Recovered on October 10, 201, at http://geocapes.capes.gov.br/geocapesds/

Guimarães-Iosif, R.M..(2009) Educação, Pobreza e Desigualdade no Brasil: impedimentos para a cidadania global emancipada. 1.ed. Brasília: Líber Livro.

Jakobi, P.A.(2007). Converging Agendas in Education Policy: Lifelong Learning in the World Bank and the International Labor Organization. In: Martens, K.; Rusconi, A.; Leuze, K. (Eds.). New Arenas of education governance: The impact of international organizations and markets. New York: Palgrave Macmillan, pp. 3-15.

Knight, J.(2007). Crossborder Education: Changes and Challenges in Program and Provider Mobility. In Leuze, K.; Martens, K.; Rusconi, A.(Eds.), New Arenas of education governance: The impact of international organizations and markets. New York: Palgrave Macmillan, pp. 136-154.

Knight, J.(2005). Model of internationalization and how to deal with new realities and challenges. In L'enseignement supérieur en Amérique latine - la dimension internationale. Paris: Organization de Coopération et de Développement Économique. Paris: OCDE.

Krawczyk. N. R.(2008). As Políticas de Internacionalização das Universidades no Brasil: o caso da regionalização no Mercosul. Journal de políticas educacionais, $\mathrm{n}^{\circ}$ 4. Julho-Dezembro, pp. 41-52.

Leuze, K.; Martens, K.; Rusconi, A.(2007). New Arenas of Education Governance - The impact of International Organizations and Markets on Education Policy Making. In Martens, K.; Rusconi, A.; Leuze, K. (Eds.). New Arenas of education governance: The impact of international organizations and markets. New York: Palgrave Macmillan, pp. 3-15.

Lima, L. C.; Azevedo. M. N.; Catani, A. M. (2008). O Processo de Bolonha, a avaliação da educação superior e algumas considerações sobre a universidade nova. Avaliação; Sorocaba, Campinas, SP, v. 13, n.1, p. 7-36, mar.

Lima, M. C.; Contel, F. B.(2009). Períodos e Motivações da Internacionalização da Educação Superior Brasileira. USP. Grenoble-FR-IFBAE.

Marrara, T.(2007). Internacionalização da Pós-Graduação: objetivos, formas e avaliação. $R P B G$, Brasília, v4, n8, p245-262.

Monteiro, S. Q. M.(2007). "Introdução: a emergência da cooperação internacional acadêmica no Brasil” in: Monteiro, S. Q. de M.; Oliveira, M. A. G. (orgs.). Cooperação internacional acadêmica: experiências e desafios. Recife: Ed. Universitária da Ufpe.

Martens, K.(2007). How To Become an Influential Actor: The 'Comparative Turn' in OECD Education Policy. In Martens, K.; Rusconi, A.; Leuze, K. (Eds.). New Arenas of education governance: The impact of international organizations and markets. New York: Palgrave Macmillan, pp. 40-56.

Minogue, K.(1991). O conceito de universidade. Brasília: UnB.

Morosini, M; Paula,M. F. A.(2009).Formação universitária no Brasil: concepções e influências. Avaliação (Campinas), Sorocaba, v.14, n. 1, mar. 
Morosini, M.(2006.). Internacionalização da Educação Superior: um modelo em construção?” In Morosini, M. (org.). A Universidade no Brasil: concepções e modelos. Brasília: INEP/MEC.

Rossato, R. (1998) Universidade: nove séculos de história. Passo Fundo: Ediupf.

Santos, B.S. (2010). A universidade do século XXI: para uma reforma democrática e emancipatoria da universidade ( $\left.3^{\mathrm{a}} . \mathrm{Ed}\right)$. São Paulo: Cortez.

Velho, L. (1998). "Políticas governamentais e motivações para aproximar pesquisa acadêmica e setor produtivo." In Velloso, J. (org.). O ensino superior e o Mercosul. Rio de Janeiro: Garamond.

World Bank. (1999). Education sector strategy. Washington, D.C.: The World Bank. 